\title{
Microstructural Evaluation of an Austempered Cast Iron Alloy
}

\author{
Letyssia Niara De Godoi Pereira ${ }^{a}$, Ronaldo Gomes de Castro Medeiros ${ }^{b}$ (D),
}

\author{
Patrícia Guimarães Monteiro de Freitas ${ }^{b}$ (D), Camila Ferreira da Silva ${ }^{a}$, Leonardo Martins da Silva ${ }^{a *}$ (D), \\ Ricardo Henriques Leal
}

\author{
${ }^{a}$ Universidade Federal Fluminense, Av. dos Trabalhadores, 420, Vila Sta. Cecília, 27255-125, \\ Volta Redonda, RJ, Brasil. \\ ${ }^{b}$ Pontifícia Universidade Católica do Rio de Janeiro, Rua Marquês de São Vicente, 225, Gávea, \\ 22541-041, Rio de Janeiro, RJ, Brasil.
}

Received: May 28, 2021; Revised: December 22, 2021; Accepted: January 13, 2022

\begin{abstract}
ADI are the result of graphite nodules and ausferrite microstructure (acicular ferrite + retained austenite). Over the past few years, ADI has become an important material for engineering due to its excellent mechanical properties (outstanding ductility, high mechanical strength and good toughness) and low cost. It is known the discussion of process variables such as austempering time and temperature are extremely important for the microstructural and hardness study of these materials. Thus, in the present work, ADI cast iron was investigated under twelve different austenitic conditions, aiming to characterize the influence of the amount of austenite on the ferritic matrix on the mechanical property of hardness. The heat treatment parameters vary from three different times $(40 \mathrm{~min}, 90 \mathrm{~min}$ and $180 \mathrm{~min})$ under four temperatures $\left(280^{\circ} \mathrm{C}, 300^{\circ} \mathrm{C}, 320^{\circ} \mathrm{C}\right.$ and $\left.370^{\circ} \mathrm{C}\right)$. Results show there is a decreasing of hardness linked to the increasing of retained austenite $\%$ volume. The greater amount of retained austenite \% volume in the matrix was presented by sample A14, treated during 40 minutes under $370^{\circ} \mathrm{C}$ and presenting $32.30 \%$ of this microconstituint. The amounts of each phase present in the studied materials were raised by quantitative metallography through the software Fiji-ImageJ, allowing a comparison of the results obtained by these two methods. Time differences on the austempering heating treatment did not show several implications on ADI microstructure. In addition, analyzes of the graphite nodules were performed.
\end{abstract}

Keywords: Austempered Ductile Iron-ADI, Metallography, Microstructure, Thermal treatment.

\section{Introduction}

Austempered Ductile Cast Iron (ADI) oustands due to its carbon stabilized austenite alongside acicular ferrite. Some of the advantages of ADI are the combination of high mechanical strength and ductility and the possibility of increasing hardness and yield stress due to induced deformation. This kind of cast iron has been investigated through decades, and due its outstanding performance, researchs still being produced. Fernandez-Valdivieso et al. ${ }^{1}$ came up with an investigation about the casting machinability of ADI, turning ADI with ceramic tools by optimizing processes with ceramic inserts.

Boneti et al. ${ }^{2}$ analyzed the microstructure and mechanical properties of an ADI, where austempering was performed in melted metal baths through a range of temperatures of $300{ }^{\circ} \mathrm{C}$ and $370{ }^{\circ} \mathrm{C}$, for 30 minutes. The study shows the microstructure found in these materials was ausferrite microstructure (acicular ferrite + retained austenite). Furthermore, it is noteworthy the same authors reports that higher austemper temperatures, e.g. $370{ }^{\circ} \mathrm{C}$, can produce a thicker ferrite, but smaller regarding its volume fraction. This is accompanied by a decreasing in yield strength and

*e-mail: leonardouffsilva@gmail.com hardness. For lower austempering temperatures, for example, $280{ }^{\circ} \mathrm{C}$, result in finer ferrite fractions with greater volume and greater flow resistance. Finally, the authors concluded that yield strength, tensile strength and hardness decrease alongside the increase of austempering temperature ${ }^{2}$.

Wang et al. ${ }^{3}$ brings ADI wear behaviour and mechanisms in question, comparing its performance in face of single-step and dual-step austempering processes ${ }^{3}$.

Tissi $^{4}$, aimed to evaluate the influence of austempering time and temperature in austempered nodular cast iron samples. The authors analyzed changes in the microstructure and mechanical properties of these materials. The samples were subjected to an austempering heat treatment with austempeting time 90 minutes for $910^{\circ} \mathrm{C}$. During the austempering bath, the samples were subjected to different temperatures $300^{\circ} \mathrm{C}, 320^{\circ} \mathrm{C}, 340^{\circ} \mathrm{C}, 360^{\circ} \mathrm{C}$ and $380^{\circ} \mathrm{C}$ for four different times for each temperature $(75,110,145$ and 180 minutes). The authors concluded all austempered samples presented graphite nodules, acicular ferrite and austenite with high carbon content in their microstructure. The study also shows that samples treated at higher austempering temperatures had lower hardness, as higher austempering temperatures lead to higher volumes of retained austenite ${ }^{4}$. 
As temperature increases, retained austenite also increases, due to greater carbon diffusion, causing hardness decrease as well. Therefore, the higher the temperature, the higher the percentage of retained austenite and therefore the lower the hardness. Finally, the study reports that the austempering time did not show significant results and, therefore, the influence of the austempering temperature on the microstructure and hardness in ADI is much more significant than the influence of time ${ }^{4}$.

The present article aims at the microstructural and mechanical characterization of nodular cast irons through metallographic analysis, hardness testing, and behavioral analysis of graphite nodules under different austempering treatment conditions. Also, authors aim to investigate the influence of austempering time on ADI microstructure and hardness, varying its treatment temperature and submitting the material to unconventional treatment conditions.

\subsection{Ductile or nodular cast irons}

Ductile or nodular cast irons are also Fe-C-Si alloys, characterized by presenting graphite in the form of spheres.

Figure 1 shows the micrograph $200 \mathrm{X}$ of magnification nodular cast iron sample.

In Figure 1, it is possible to observe the spheroidal shape of the graphite (hence the nodular name due to the graphite nodules) without interrupting the continuity of the matrix and for this reason its mechanical properties such as ductility, toughness and strength are better than those of lamellar cast iron, because the graphite lamellae weaken the material ${ }^{5,6}$.

\subsection{Austempered Nodular cast iron (ADI)}

The ADI is obtained through heat treatment of austempering in nodular cast iron. Eltaggaz et al. ${ }^{7}$ argues that its unique ausferrite microstructure contributes to several properties. This resulting ausferrite (acicular ferrite in the middle of high carbon austenite) results in high values of mechanical

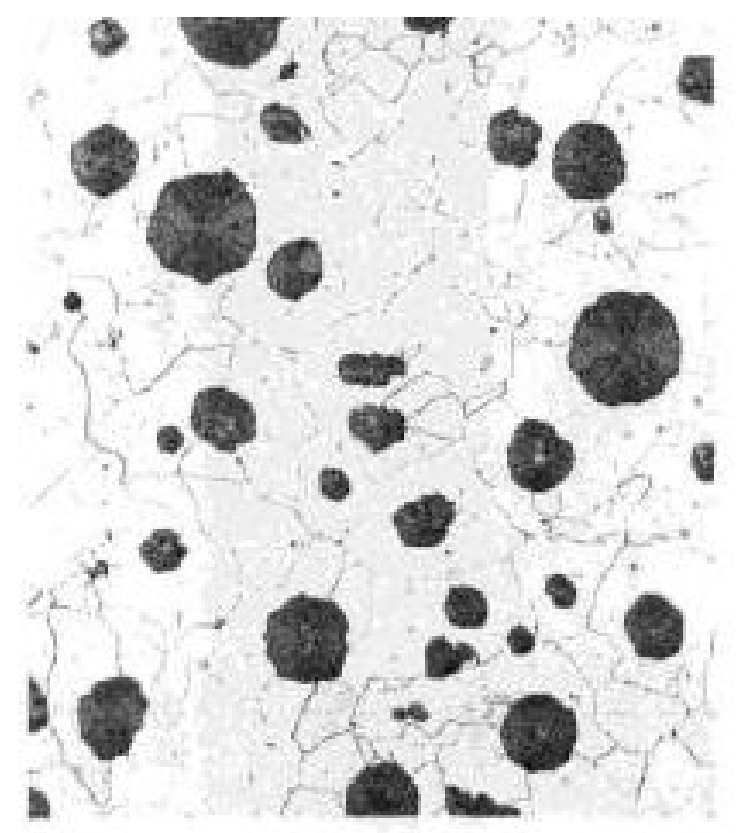

Figure 1. Optical micrograph of a nodular cast iron with a 200 -fold magnification $^{5}$. strength, ductility, impact resistance and wear resistance ${ }^{2,8}$. Thus, the material provides great flexibility in the design and manufacture of parts ${ }^{9-12}$.

The austempering heat treatment was initially developed for steels by Davenport and Bain in 1930. Subsequently, the resulting microstructure - carbide ferrite - was named bainite in honor of Bain ${ }^{13,14}$.

According to Kovacs ${ }^{15}$ when the structure of ADI was observed for the first time, it was thought to be bainite, as in steels, and, therefore, many articles and patents related to ADI called it bainite. A few years later, X-ray analysis proved that the structure was not bainite. However, today it is known that ausferrite and bainite are completely different constituents, since ausferrite is composed of ferrite and austenite, while bainite is composed of ferrite and carbides.

After several years of research to identify the microstructure and give it a correct name, in 1992, the ausferrite name was recognized ${ }^{10,16,17}$.

According to ASTM A $897 \mathrm{M}-1997^{18}$ the microstructure resulting from this heat treatment is formed by acicular ferrite and austenite.

Figure $2 \mathrm{a}$ and $\mathrm{b}$ illustrate ausferritic microstructures, produced with austemper temperatures around $370{ }^{\circ} \mathrm{C}$ and $260{ }^{\circ} \mathrm{C}$ respectively.

Figure 2 a shows a coarse ausferrite, composed of approximately $60 \%$ acicular ferrite (dark region) and $40 \%$ high carbon austenite (light region). However, Figure $2 \mathrm{~b}$ shows a refined ausferrite, composed of approximately $85 \%$ of acicular ferrite (dark region) and $15 \%$ of high carbon austenite (light region). However, some authors believe that at a temperature of $260{ }^{\circ} \mathrm{C}$, carbide precipitation already occurs, even in short maintenance times ${ }^{16}$.

\subsubsection{Ferrite ( $\alpha$ iron)}

Ferrite (from the Latin "ferrum"), a solid solution of carbon and iron in the allotropic state of pure iron, contains traces of carbon in solution, stable below $910^{\circ} \mathrm{C}$ and crystallizes in the centered body cubic system. Also called alpha iron. Compared with other constituents, ferrite is not very hard, with Brinell hardness equal to $80^{6}$.

\subsubsection{Austenite}

Austenite is a solid solution of carbon and gamma iron, has a CFC crystalline structure, existing between temperatures of $727^{\circ}$ and $1495^{\circ} \mathrm{C}$, and with maximum carbon solubility in iron of $2.11 \%$ at $1148^{\circ} \mathrm{C}$. It has good mechanical resistance and appreciable toughness and is not magnetic ${ }^{6}$.

\subsubsection{Graphite}

Unlike the two constituents previously mentioned, also found in common steels, this is typically characteristic of cast irons. It is formed, practically, by pure carbon arranged in layers, being able to assume different shapes, dispositions and sizes. It has low mechanical resistance and hardness between 1 and 2 Mohs $^{6}$.

\subsection{Mechanical properties}

Due to the excellent combination of mechanical properties, such as tensile strength, fatigue strength, ductility, toughness and wear resistance. It has competitive mechanical properties as compared with conventional cast irons ${ }^{19}$. These mechanical properties are due to its singular microstructure of acicular 

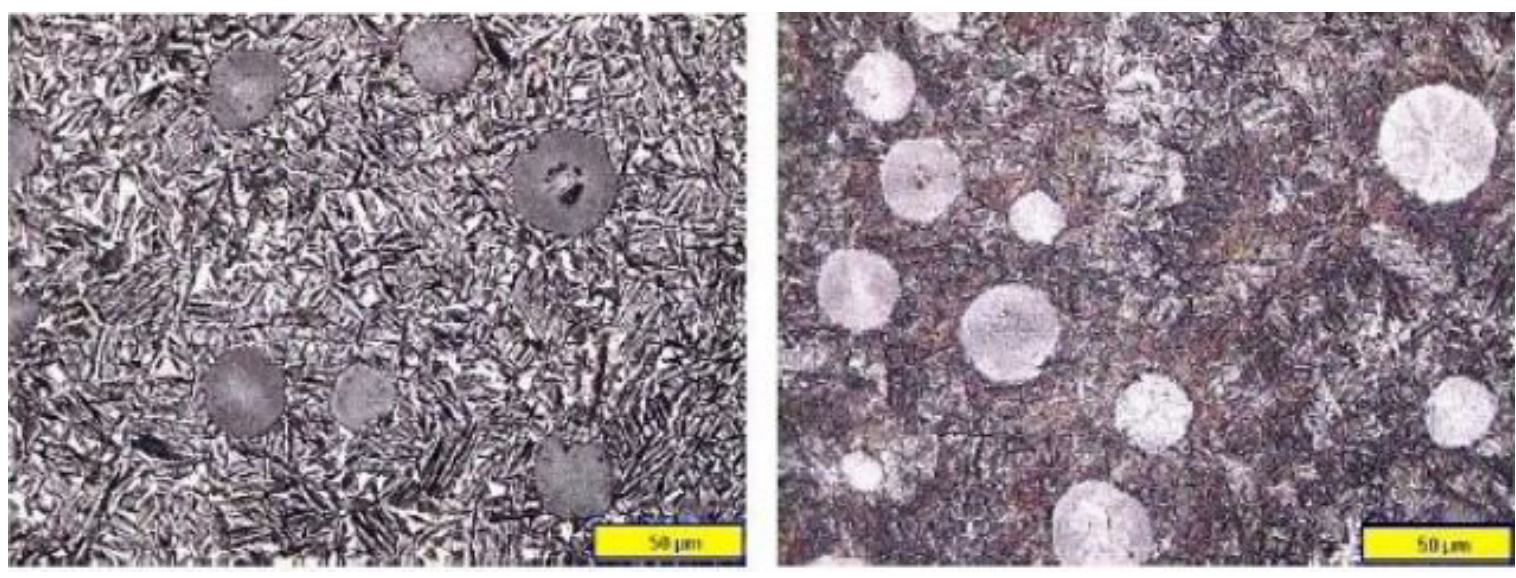

Figure 2. Typical micrographs of austempered nodular cast iron, with a 5\% Nital attack, according to the ASTM-897 standard ${ }^{18}$ a) coarse ausferrite 1 ; b) refined ausferite. Graphite nodules and ausferritic matrix, which is composed of bainitic ferrite.

ferrite and retained austenite ${ }^{20}$. In addition, ADI has a density $10 \%$ lower than steel, because of the graphite nodules and has the best weight ratio by yield limit $^{16}$.

Through the Table 1 below, we can obtain a better view of the main characteristics of the ADI. It shows the results of the tensile, impact and hardness tests of various classes of ADI using the ASTM standard.

Thus, in the present work, the characterization of phases present in the matrix of twelve samples of ADI was carried out, submitted to different conditions of austempering. This characterization was obtained through optical micrograph, with a qualitative and quantitative analysis of the phases present in each samplewith. Quantitative characterization was performed using the Fiji-ImageJ software. In addition, an analysis of the graphite nodules was also carried out according to their twelve austempering conditions.

\section{Materials and Methods}

The ADI samples used in this work were received but were already heat treated in 12 different conditions of time and temperature, and one of them in the raw state of fusion $(\mathrm{BF})$. A range of temperatures was chosen in order to promote amounts of retained austenite between $20 \%$ and $40 \%{ }^{21}$. The different conditions of the respective austempêra treatments were: with temperatures and times varying, respectively, between $280^{\circ} \mathrm{C}$ and $370{ }^{\circ} \mathrm{C}$ and $40 \mathrm{~min}$ at 3 hours, are shown in Table 2.

The samples, Figure 3, were subjected to analysis by optical micrography, hardness tests and the software Fiji ImageJ, aiming at the identification and quantification of the phases present at the end of each heat treatment and its consequent influence on the hardness of each material.

\subsection{Sample preparation}

In order to perform sanding and polishing of the samples was used STRUERS polishing/sanding machine, model KNUTH-ROTOR 2 and Polishing Teclago model PL02EP.

\subsection{Metallographic analysis}

For the evaluation of the microstructure and the recording of images, the optical micrograph technique was used.

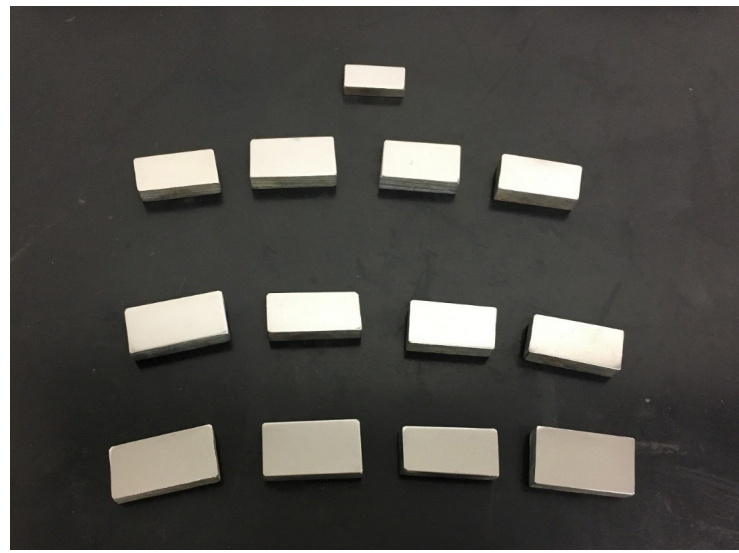

Figure 3. ADI samples used in this work.

Table 1. Standard ASTM A89718 - austempered nodular cast iron, with minimal properties.

\begin{tabular}{cccccc}
\hline Class & $\begin{array}{c}\text { Resistance } \\
\text { limit } \\
(\mathrm{MPA})\end{array}$ & $\begin{array}{c}\text { Yield } \\
\text { limit } \\
(\mathrm{MPa})\end{array}$ & $\begin{array}{c}\text { Stretching } \\
(\%)\end{array}$ & $\begin{array}{c}\text { Impact } \\
\text { energy } \\
(\mathrm{J})\end{array}$ & $\begin{array}{c}\text { Hardness } \\
(\mathrm{HB})\end{array}$ \\
\hline 1 & 850 & 550 & 10 & 100 & $269-321$ \\
\hline 2 & 1050 & 700 & 7 & 80 & $302-363$ \\
\hline 3 & 1200 & 850 & 4 & 60 & $341-444$ \\
\hline 4 & 1400 & 1100 & 1 & 35 & $366-477$ \\
\hline 5 & 1600 & 1300 & $\mathrm{~N} / \mathrm{A}$ & $\mathrm{N} / \mathrm{A}$ & $444-555$ \\
\hline
\end{tabular}

The micrographs were obtained with the aid of the Nikon Eclipse LV 150 optical microscope.

Microstructure evaluations were carried out without and with chemical attack. The metallographic analysis without chemical attack aimed at identifying the graphite nodules generated in each heat treatment, their sizes and distributions, and changes in the graphite nodules in relation to the received raw melting material. The metallographic analysis with chemical attack aimed at the identification of the present phases and their quantification.

The initial idea of the work was to carry out the chemical attack with a $3 \%$ solution of Nital, by immersion for four 
seconds, but due to unwanted results it was discarded. The solution found for this problem was to carry out the colored chemical attack with the Beraha solution, of composition: $5 \mathrm{ml}$ of distilled water, $5 \mathrm{ml}$ of hydrochloric acid and 0.1 gram of potassium metabisulfite, the attack was carried out by immersion for 15 seconds.

\subsection{Microscopic and quantitative analyzes}

The necessary procedures for performing the optical micrograph were performed in the Microstructural Characterization laboratory of the Federal Fluminense University - EEIMVR.

\subsection{Hardness test}

The Brinell scale was used to determine the hardness of the samples in this work, and the test was carried out at the Mechanical Testing Laboratory of Universidade Federal Fluminense - EEIMVR. The samples were previously sanded in order to obtain a flat and smooth surface and free from oxidation, and tested 3 times each, with a $2.5 \mathrm{~mm}$ steel ball penetrator, load equal to $187.5 \mathrm{Kgf}$ for 15 seconds, according to NBR NM 187-1 ${ }^{22}$, on a Brinell HECKERT HPO 250 WPM hardness machine.

The determination of hardness by the Brinell scale presents some inaccuracy due to the mechanical handling of the machine and the reading is not direct, thus requiring an interpretation by the observer to measure the values of the printing diameters and from there to treat the data to obtain the value of hardness.

\section{Results and Discussion}

\subsection{Microstructural analysis}

The microstructural characterization of the samples was carried out using the techniques of optical micrography (OM),
Brinell hardness test and phase quantification. The results are grouped by sample, where each sample has already been identified in the previous section.

Figure 4 shows micrographs of the samples chemically attacked with $3 \%$ Nital for 3 and 4 seconds, respectively.

In Figure 4, it is possible to observe that this type of chemical attack was not successful for the samples in question, because the chemical attack burned the samples, making it difficult to identify and quantify the phases, requiring another chemical attack.

\subsubsection{BF sample}

The sample in the raw state of fusion $(\mathrm{BF})$, presents a reasonable amount of nodules, with different sizes, as we can see in Figure 5.

The morphology of the nodules in this sample does not entirely present uniform geometries, as can be seen in Figure 5.

\subsubsection{Sample $A 2$ and $A 17$}

In order to evaluate the different properties that occurred in the samples at different temperature variations, the properties observed in samples A2 and A17 were presented. Sample A2 It is a nodular cast iron sample that has undergone austemperature heat treatment under the conditions of $280^{\circ} \mathrm{C}$ and 0.67 hours and the sample A17 is a nodular cast iron sample, which has undergone austempering heat treatment under the conditions of $370^{\circ} \mathrm{C}$ and 3.0 hours, as indicated in Table 2 of the previous section.

After performing the heat treatment on the sample, it can be seen through Figure 6 that the graphite nodules apparently have an increase in size when compared to the BF sample.

Analyzing the nodules in a higher magnification lens, as in Figure 7, it is observed a homogenization in the format of the graphite nodules of samples A2 and A17 in relation to the graphite nodules of the sample BF. It is also possible to

Table 2. Identification of worked samples.

\begin{tabular}{|c|c|c|c|c|c|c|c|c|c|c|c|c|c|}
\hline & A2 & A3 & A5 & A6 & A7 & A9 & A10 & A11 & A13 & A14 & A15 & A17 & $\mathbf{B F}$ \\
\hline Temperature $\left({ }^{\circ} \mathrm{C}\right)$ & 280 & 280 & 280 & 300 & 300 & 300 & 320 & 320 & 320 & 370 & 370 & 370 & -- \\
\hline Time $(\mathrm{h})$ & 0,67 & 1,5 & 3,0 & 0,67 & 1,5 & 3,0 & 0,67 & 1,5 & 3,0 & 0,67 & 1,5 & 3,0 & -- \\
\hline
\end{tabular}

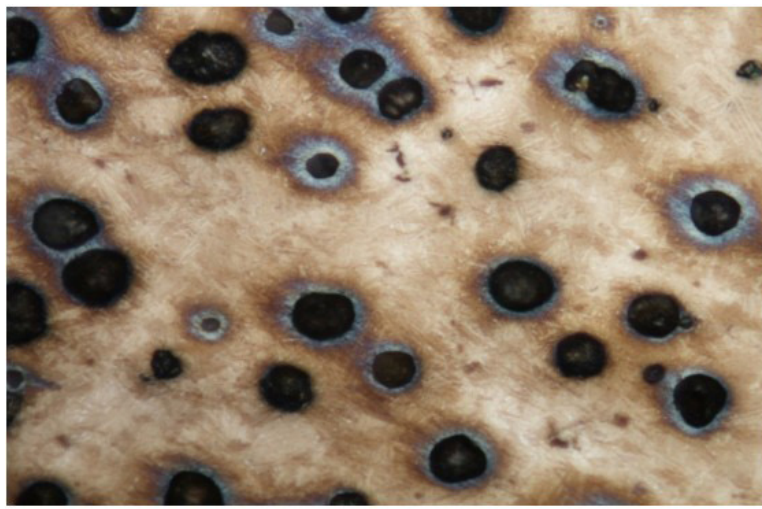

(a)

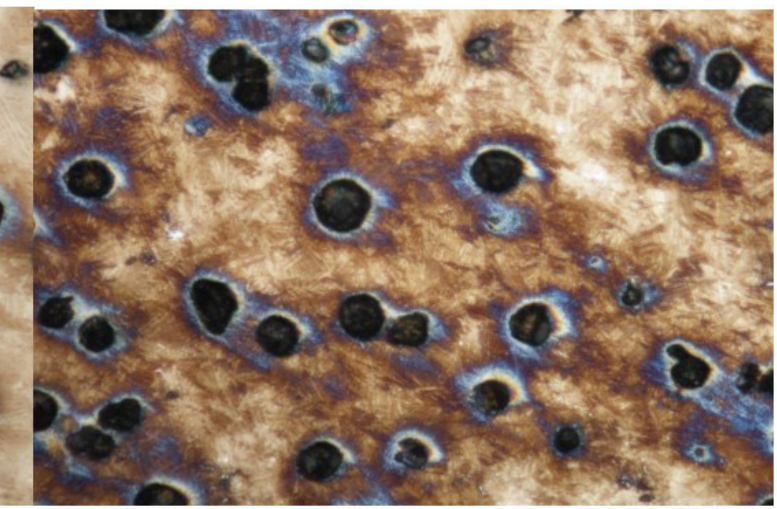

(b)

Figure 4. (a) Microstructure of sample A2. Attack with 3\% Nital for 3 seconds. Optical micrograph with 500X magnification and (b) - Microstructure of the A5 sample. Attack with 3\% Nital for 4 seconds. Optical microgaphy with 200X magnification. 
notice the tearing of graphite resulting from the preparation of the samples.

\subsection{Identification and quantification of matrix phases}

The Beraha colored chemical attack was used in order to reveal and quantify the phases present in samples A2 and A17.

Through optical microscopy analysis it was possible to verify that the material matrix is constituted by acicular ferrite, which is presented in blue and by retained austenite represented in white, as it is possible to observe through Figure 8.

The percentages of the ferrite and retained austenite phases resulting from the austempering treatment in samples A2 and A17, are shown in Tables 3.

In addition, as can be seen also seen in Figure 8, some regions are brown, these are not phases in question, but a burning principle in the matrix resulting from the chemical attack.
This color profile is maintained for all samples of ADI cast iron attacked by the Beraha reagent in the present work.

\subsection{Hardness test}

As previously mentioned, the hardness samples were tested 3 times each.

The result of the mean and standard deviation of the hardness measures of sample A2 was:

$H B=(341.37 \pm 3.08)$

The result of the mean and standard deviation of the hardness measures of sample A17 was:

$H B=(334.12 \pm 11.12)$

The important factor to note is how the amount of austenite and the hardness of the material behaved with the variations in time and temperature of the heat treatment, as shown in Figure 9.

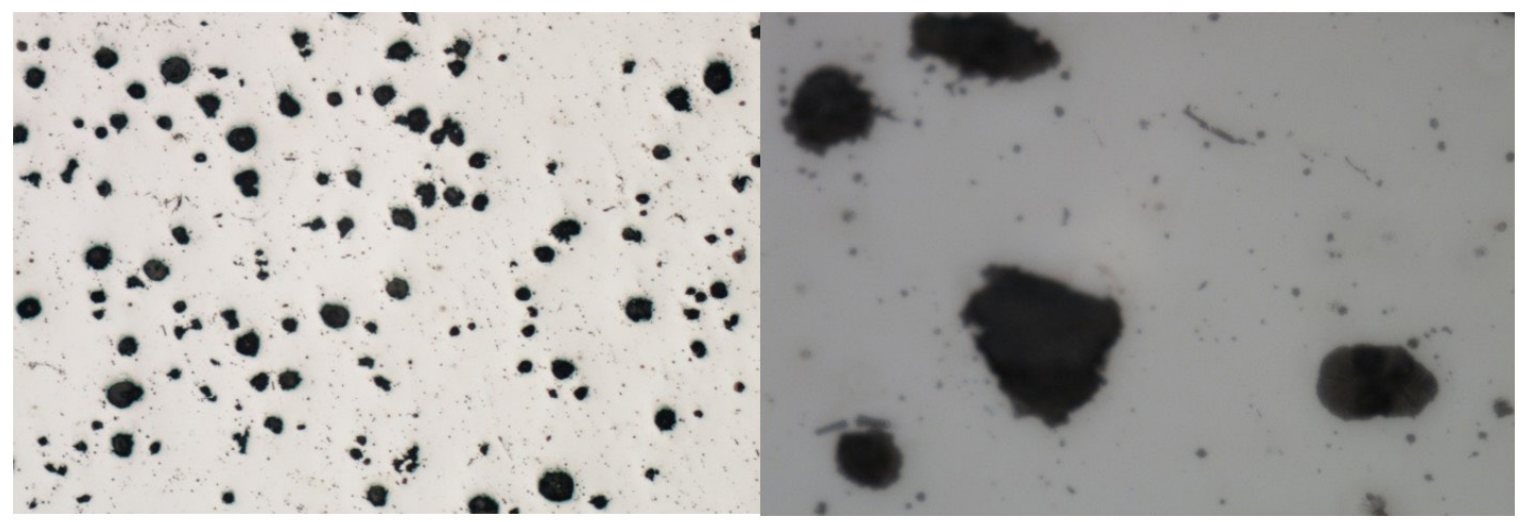

(a)

(b)

Figure 5. (a) Optical micrograph of the BF sample optical micrograph with $100 \mathrm{X}$ magnification and (b) Optical micrograph of the BF sample with 500X magnification.

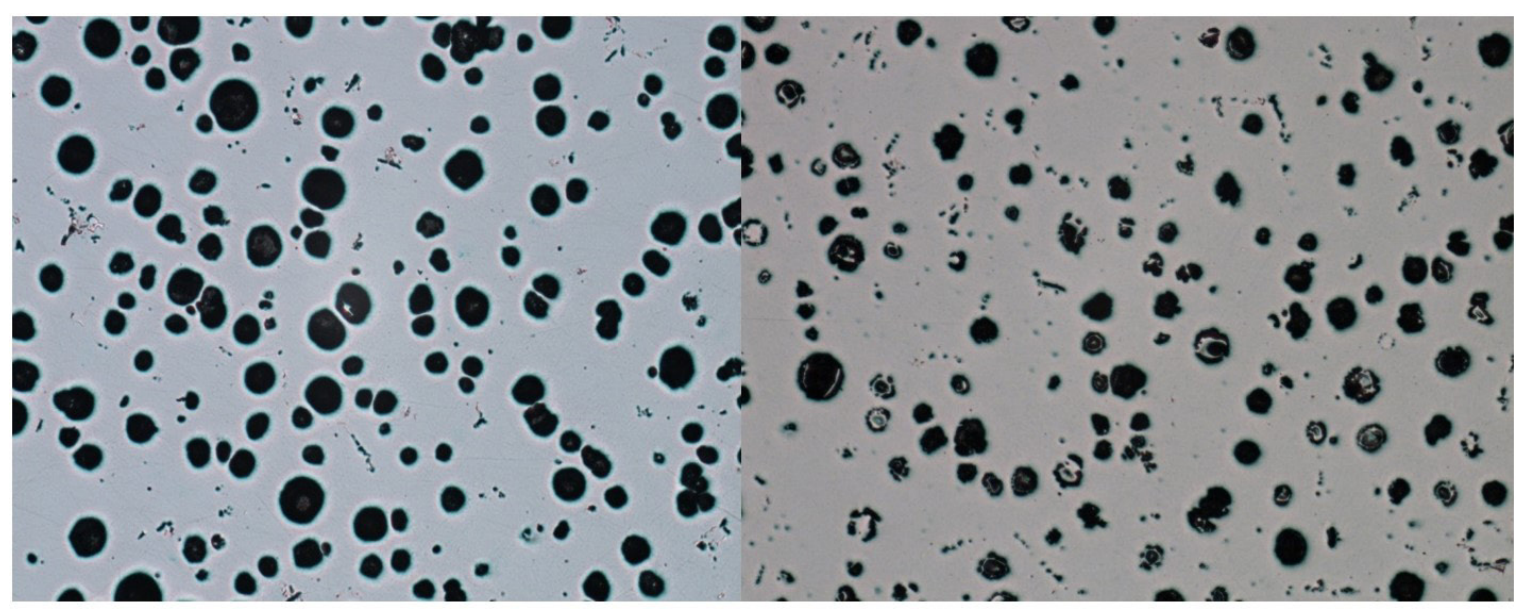

(a)

Figure 6. (a) Optical micrograph of sample A2 without attack with 100x magnification and (b) Optical micrograph of sample A17 without attack with 100x magnification. 


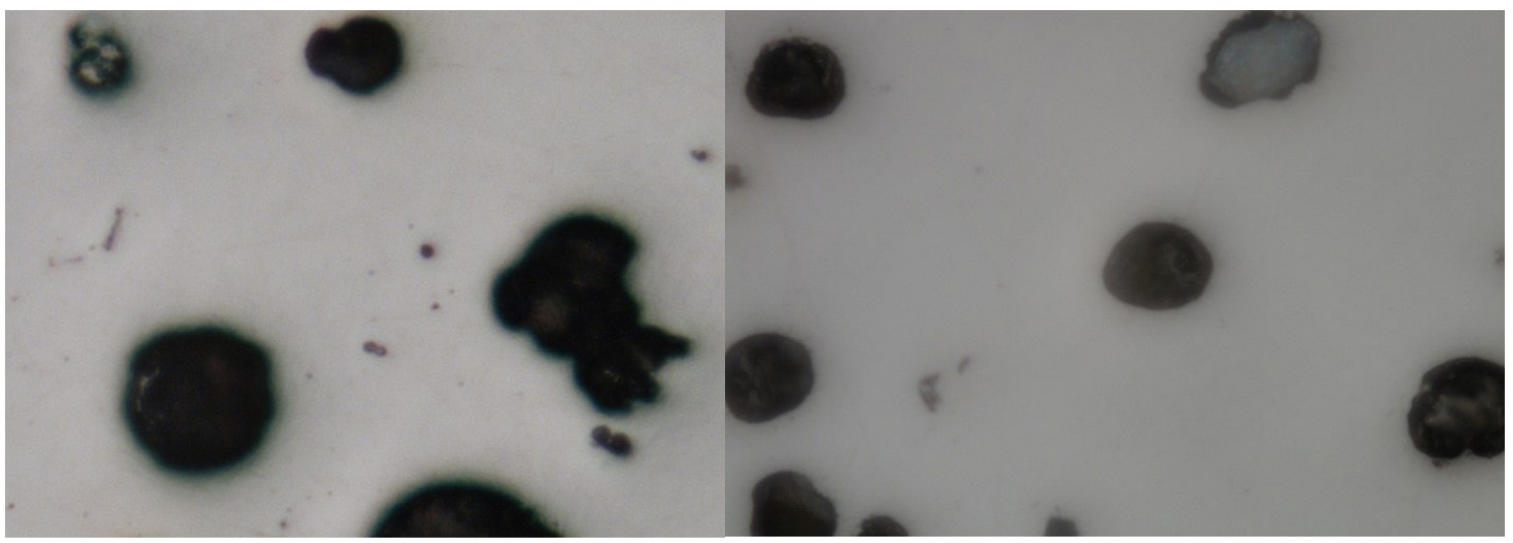

(a)

(b)

Figura 7. (a) Optical micrograph of sample A2 without attack with 500x magnification and (b) Optical micrograph of sample A17 without attack with 500x magnification.

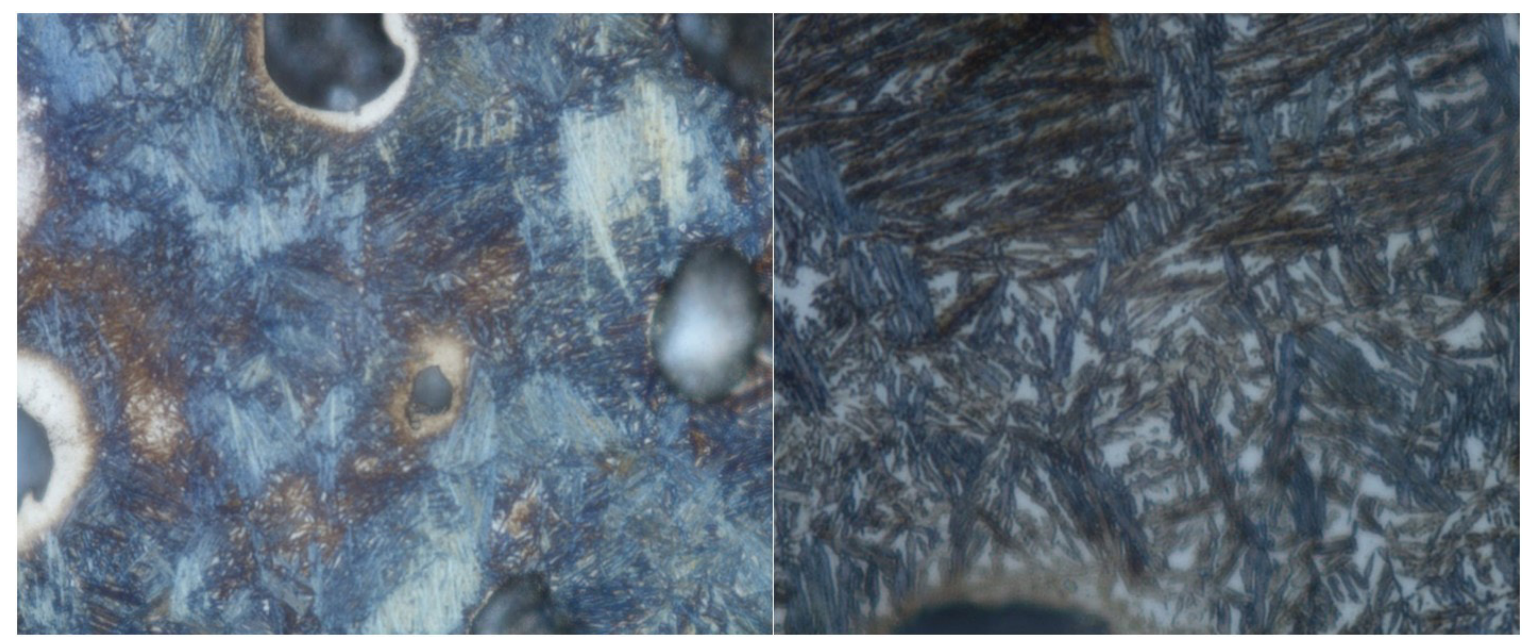

(a)

(b)

Figure 8. (a) Optical micrograph of sample A2 with Beraha attack, acicular ferrite: blue color. Retained austenite: white color with 500x magnification and (b) Optical micrograph of the sample A17 with Beraha attack, Acicular ferrite: blue color. Retained austenite: white color. With 500x magnification.

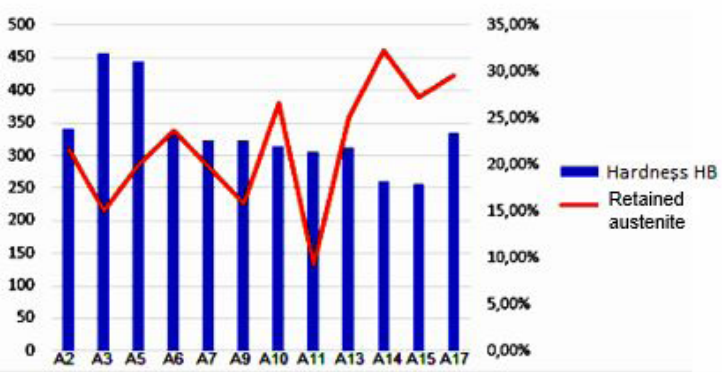

Figure 9. Graph. Hardness (HB) x \% Volume Retained austenite.

Analyzing the temperature variation, Figure 10, for each of the three austempering treatment times, it is observed that with the increase in the austempering treatment temperature, the percentage of retained austenite shows a growth trend. According to Du et al. ${ }^{23}$ mechanical properties of ADI are affected by its phase constutuints due to the carbon saturated retained austenite.

It can be noticed a tendency in \% volume of retained austenite. Excepting the samples treated under $320^{\circ} \mathrm{C}$, those treated on 280,300 and $370^{\circ} \mathrm{C}$ presents an increasing of $\%$ volume for retained austenite. According to Bendikien et al. ${ }^{8}$, higher austempering temperatures produces gross acicular ferrites. Also, the increasing of austempering temperature leads to a higher $\%$ volume of retained austenite, contributing to the hardness decrease ${ }^{2,4}$.

Figure 11 shows the graph of hardness and percentage of retained austenite in the heat-treated materials for 180 minutes.

As seen through Figures 9, 10 and 11, for the same austempering time, the higher the percentage of retained austenite, the smaller amount of acicular ferrite, the harder 
Table 3. Data summary of the 12 samples tested.

\begin{tabular}{|c|c|c|c|c|c|c|}
\hline Sample & $\begin{array}{l}\text { Austempering } \\
\text { time (hours) }\end{array}$ & $\begin{array}{l}\text { Austempering } \\
\text { temperature }\left({ }^{\circ} \mathrm{C}\right)\end{array}$ & Ferrite $(\%)$ & $\begin{array}{c}\text { Retained } \\
\text { austenite (\%) }\end{array}$ & Hardness (HB) & Nodular behavior \\
\hline $\mathrm{A} 2$ & 0.67 & 280 & 78.4 & 21.6 & 341 & $\begin{array}{c}\text { Grew and } \\
\text { homogenized }\end{array}$ \\
\hline A3 & 1.50 & 280 & 85.0 & 15.0 & 457 & $\begin{array}{c}\text { Grew and } \\
\text { homogenized }\end{array}$ \\
\hline A5 & 3.0 & 280 & 79.9 & 20.1 & 444 & $\begin{array}{c}\text { Grew and } \\
\text { homogenized }\end{array}$ \\
\hline A6 & 0.67 & 300 & 76.4 & 23.6 & 333 & $\begin{array}{c}\text { Grew and } \\
\text { homogenized }\end{array}$ \\
\hline A7 & 1.50 & 300 & 80.2 & 19.8 & 323 & $\begin{array}{c}\text { Grew and } \\
\text { homogenized }\end{array}$ \\
\hline A9 & 3.00 & 300 & 84.2 & 15.8 & 324 & $\begin{array}{c}\text { Grew and } \\
\text { homogenized }\end{array}$ \\
\hline A10 & 0.67 & 320 & 73.4 & 26.6 & 315 & $\begin{array}{c}\text { Grew and } \\
\text { homogenized }\end{array}$ \\
\hline A11 & 1.50 & 320 & 90.7 & 9.3 & 305 & $\begin{array}{c}\text { Grew and } \\
\text { homogenized }\end{array}$ \\
\hline A13 & 3.00 & 320 & 75.0 & 25.0 & 312 & $\begin{array}{c}\text { Grew and } \\
\text { homogenized }\end{array}$ \\
\hline A14 & 0.67 & 370 & 67.7 & 32.3 & 261 & $\begin{array}{c}\text { Grew and } \\
\text { homogenized }\end{array}$ \\
\hline A15 & 1.50 & 370 & 72.7 & 27.3 & 257 & Remained \\
\hline A17 & 3.00 & 370 & 70.4 & 29.6 & 334 & $\begin{array}{c}\text { Grew and } \\
\text { homogenized }\end{array}$ \\
\hline
\end{tabular}
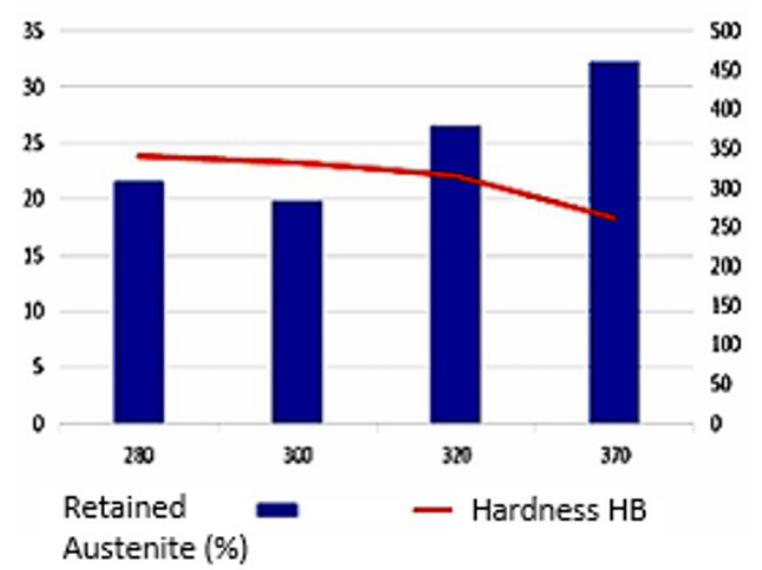

(a)

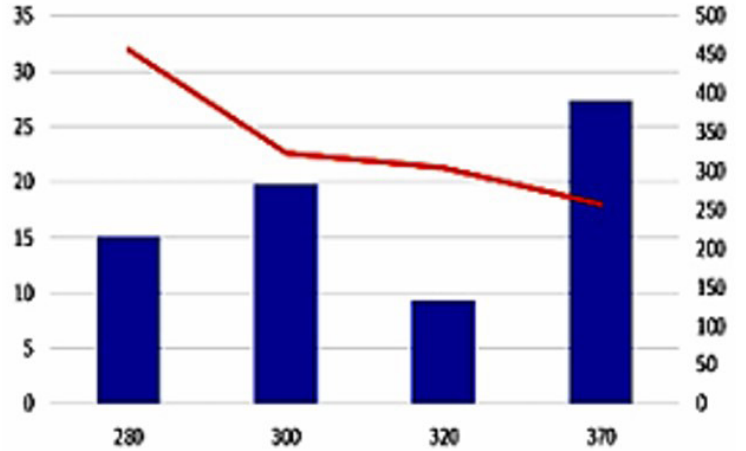

Retained Austenite (\%)

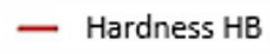

Figure 10. (a) Graph of hardness and percentage of retained austenite in materials heat treated for 40 minutes and (b) heat treated for 90 minutes.

phase, in the austempered nodular cast iron and the lower the hardness.

This result is also a consequence of the higher activation energy for the formation of inferior ausferrite compared to the superior ausferrite, as mentioned by Campos-Cambranis et al. ${ }^{24}$, which leads to an increase in the percentage of retained austenite with an increase in the treatment temperature for the same time.

Analyzing the time variation for each austempering treatment temperature, as shown in Figures 12 and 13, it is observed that the results suggest stability or a slight reduction in retained austenite contents with the increase in time for all temperatures.

It can be noticed that the austempering time did not show significant changes and, therefore, the influence of the austempering temperature on the microstructure and hardness in ADI is much more significant than the influence of time.

On the other hand, the hardness results indicate stability at $300{ }^{\circ} \mathrm{C}$ and $320^{\circ} \mathrm{C}$ and increase at $370^{\circ} \mathrm{C}$ with longer austemper times, even with a slight reduction in the retained austenite content. These results may be linked to carbide precipitation for longer treatment times, but they would need 
to be further analyzed to prove this hypothesis. Results at $280{ }^{\circ} \mathrm{C}$, with a significant increase in hardness for longer times, would need to be analyzed further.

Through Table 3, it can be seen that each sample tested underwent austempering treatment with variations in time and temperature. These variations directly influenced the properties of the material.

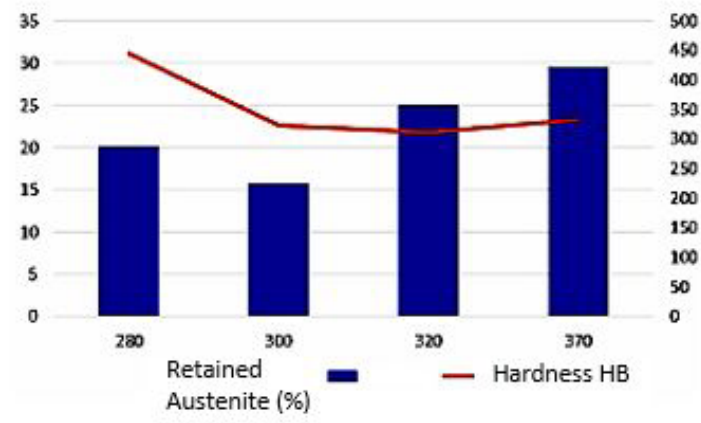

Figure 11. Graph of hardness and percentage of retained austenite in thermally treated materials for 180 minutes.
According to each austempering condition, the ADI matrix presented a different percentage of phases, thereby directly influencing the mechanical properties of the material.

The phase quantification was based on the quantification of retained austenite, due to the influences it has on the material, in particular the hardness. Theoretically, the higher the percentage of retained austenite, the lower the material's hardness should be, due to the fact that retained austenite is the softer phase of the matrix in question, as acicular ferrite is a phase of greater hardness due to its carbon saturation.

\subsection{Effect of time and temperature variation on the formation of ferrite and retained austenite}

Figure 14 shows the profiles of ferrite formation as a function of the variation in the treatment time and temperature of the samples.

Figure 14 presented the Profile of ferrite formation as a function of the variation of time and temperature of treatment of the samples where it was possible to observe that in higher values of time in values of temperatures up to $350^{\circ} \mathrm{C}$ high values of ferrite formation were found.

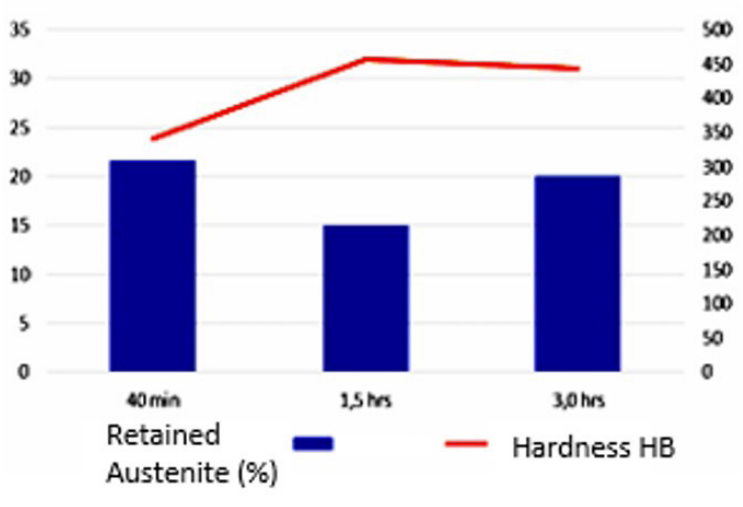

(a)

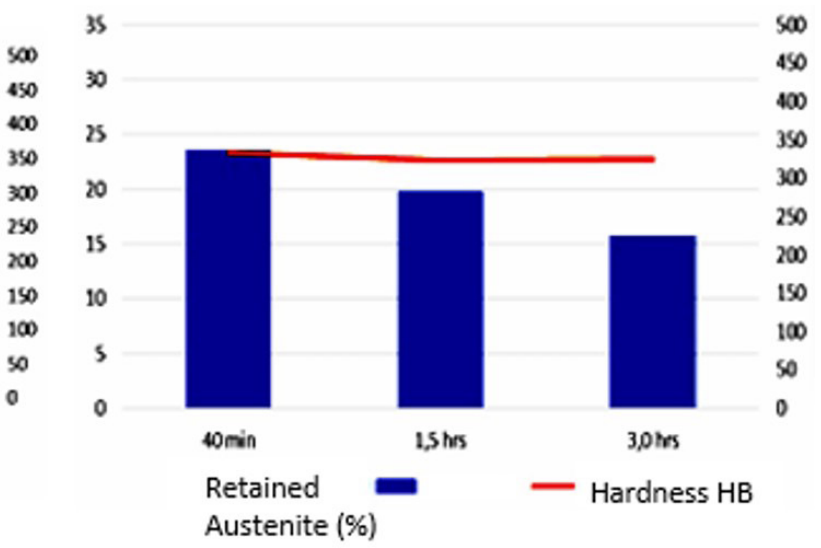

(b)

Figure 12. (a) Graph of hardness and percentage of retained austenite in materials heat treated at $280{ }^{\circ} \mathrm{C}$ and (b) heat treated at $300{ }^{\circ} \mathrm{C}$.

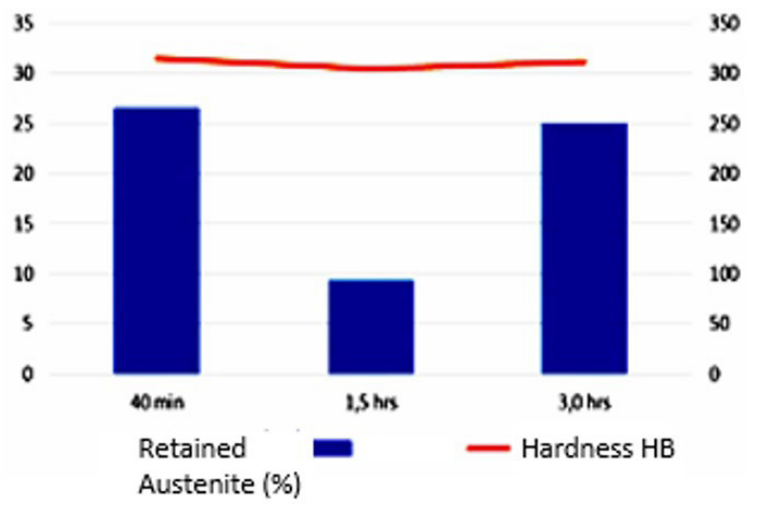

(a)

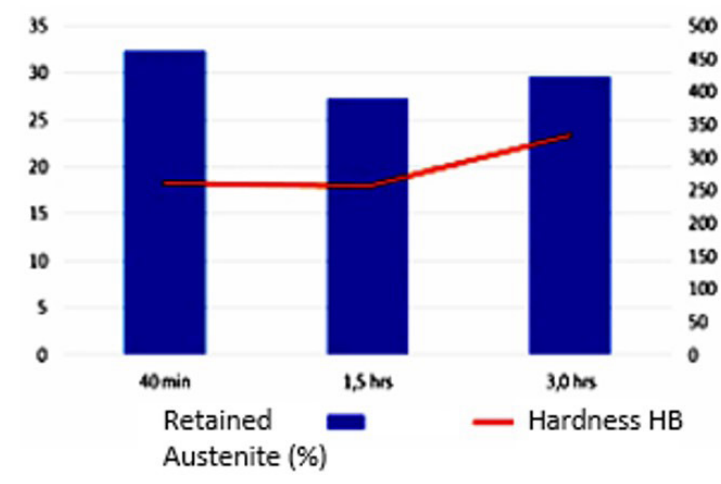

(b)

Figure 13. (a) Graph of hardness and percentage of retained austenite in materials heat treated at $320^{\circ} \mathrm{C}$ and (b) heat treated at $370{ }^{\circ} \mathrm{C}$. 
FERRITE $=$ Distance Weighted Least Squares

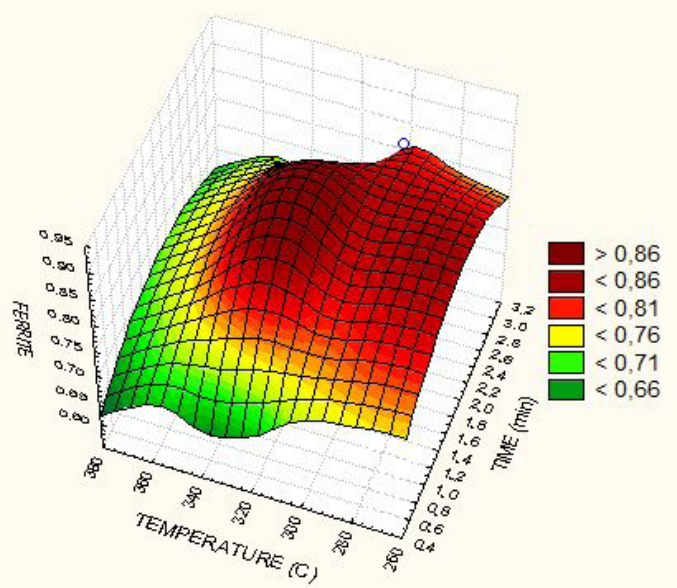

Figure 14. Ferrite formation profile as a function of the variation of time and temperature of treatment of the samples.

\section{AUSTENITE $=$ Distance Weighted Least Squares}

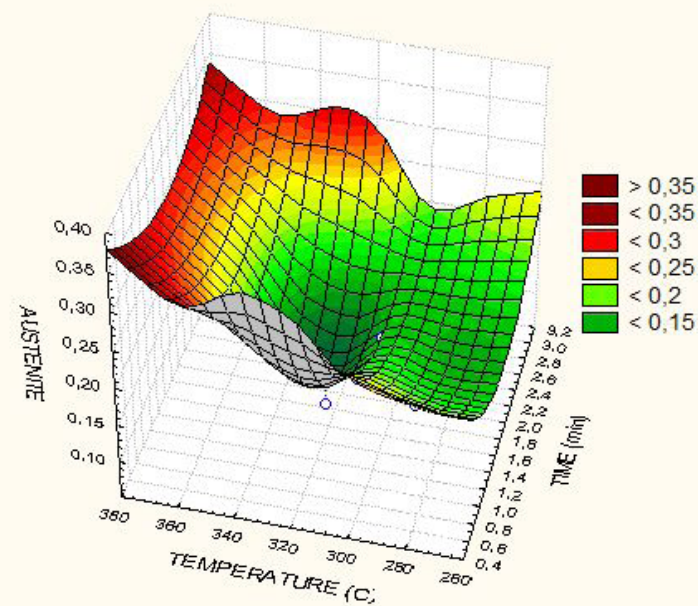

Figure 15. Profile of retained austenite formation according to the variation of time and temperature of treatment of the samples.

In Figure 15, the retained austenite formation profile is presented as a function of the variation in time and temperature of treatment of the samples.

Figure 15 presented the retained austenite formation profile as a function of the variation of time and temperature of the treatment of the samples, where it was possible to observe that higher values of the retained austenite content were found in high temperature values and it is also possible to observe that time values do not have great influence in the increase of retained austenite formation in the sample.

Figure 16 shows the hardness profile as a function of the variation in time and temperature of treatment of the samples.

Figure 16 presented the hardness profile as a function of the variation in time and temperature of treatment of the samples, where it was possible to observe that higher values of the hardness content were found in lower values of temperature throughout the time interval.
HARDNESS = Distance Weighted Least Squares

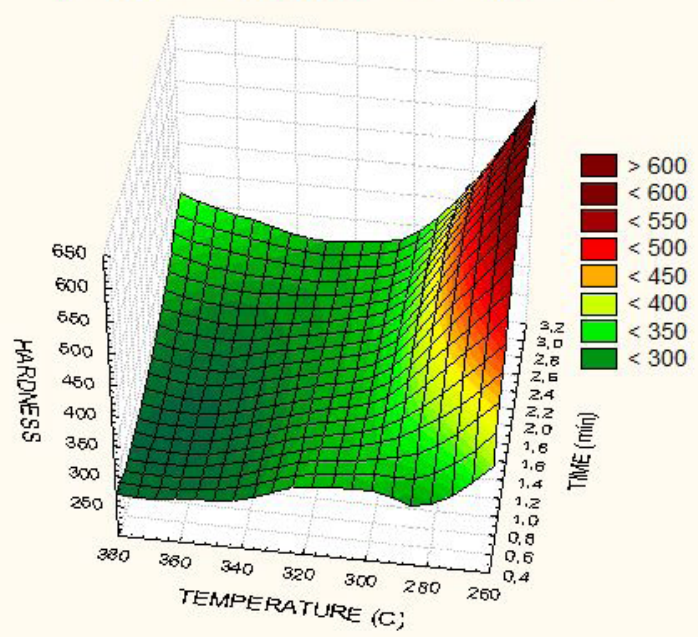

Figure 16. Hardness profile as a function of the variation of time and temperature of treatment of the samples.

\section{Conclusion}

The microstructural characterization, phase quantification and the hardness test of the Austemperated Nodular Cast Iron, allowed to conclude that:

- The Beraha attack requires a lot of care and speed to carry out its analysis, as it changes quickly over time;

- The most favorable condition for a greater amount of retained austenite in the matrix was the condition of sample A14 (40 minutes and $\left.370^{\circ} \mathrm{C}\right)$, presenting $32.30 \%$;

- The greatest hardness occurred in sample A3 $\left(1.5\right.$ hours and $300{ }^{\circ} \mathrm{C}$ ), which can also be proven because it is the sample with the highest percentage of ferrite;

- As the heat treatment temperature increases, the percentage of retained austenite tends to increase and the hardness of the material tends to decrease for the same austempering time;

- The increase in time for the same austempering temperature has inexpressive impact on the percentage of retained austenite and hardness, but this fact needs to be analyzed more deeply;

- It was possible to verify tha an unusual austempering time such as $3 \mathrm{~h}$ has a insignificant impact on the $\%$ volume of retained austenite.

\section{Acknowledgements}

The authors thank the funding agencies: Coordination of Improvement of Higher Education Personnel, (CAPES). Ministry of Science and Technology. They also thank the Metallurgical Engineering graduate program of the Fluminense Federal University for the scientific technical support.

\section{References}

1. Fernández-Valdivielso A, López de Lacalle LN, FernándezLucio P, González H. Turning of austempered ductile Iron 
with ceramic tools. Proc Inst Mech Eng, B J Eng Manuf. 2021;235(3):484-93.

2. Boneti LLT, Hupalo MF, Vurobi S Jr, Rosário AM. Influence of casting heterogeneities on microstructure and mechanical properties of austempered ductile iron (ADI). Matéria (Rio de Janeiro). 2017;22(3):1-9. http://dx.doi.org/10.1590/S1517707620170003.0192 .

3. Wang B, Qiu F, Barber GC, Pan Y, Cui W, Wang R. Microstructure, wear behavior and surface hardening of austempered ductile iron. Journal of Materials Research and Technology. 2020;9(5):9838-55.

4. Tissi GV, Fonseca GS. (2020). Influence of austempering time and austempering temperature in microstructure and mechanical properties in austempered ductile iron. Int $\mathrm{J}$ Res -Granthaalayah. 8(6):51-62. http://dx.doi.org/10.29121/ granthaalayah.v8.i6.2020.419.

5. Callister WDC Jr. Ciência e engenharia de materiais: uma introdução. 8. ed. Rio de Janeiro: LTC; 2012. 590 p.

6. Chiaverini V. Aços e ferros fundidos. São Paulo: Associação Brasileira de Metais; 1991. 2 v. p. 638-58.

7. Eltaggaz, A, Hegab H, Deiab I, Kishawy HA. Hybrid nanofluid-minimum quantity lubrication strategy for machining Austempered Ductile Iron (ADI). Int J Interact Des Manuf. 2018;12:1273-81. http://dx.doi.org/10.1007/s12008-018-0491-7.

8. Bendikiene R, Ciuplys A, Cesnavicius R, Jutas A, Bahdanovich $\mathrm{A}$, Marmysh D, et al. Influence of austempering temperatures on the micro structure and mechanical properties of austempered ductile cast iron. Metals. 2021;11(6):967.

9. Hayrynen, K. L. ADI: another avenue for ductile iron foundries. Schaumburg: Modern Casting.

10. Crocker M. ADI é alternativa para as fundições de ferro fundido nodular. Fundição e Serviços. 1998;9(69):18-22.

11. Carmo DJ, Dias JF. Ferro fundido nodular austemperado ADI. Itaúna: SENAI MG; 2001.

12. Hasse, S. ADI, um material ideal para a produção de peças com paredes espessas. São Paulo: Fundição e Serviços; 1998; p. 60-74.
13. Zimba J, Simbi DJ, Navara E. Austempered ductile iron: an alternative material for earth moving components. Cement Concr Compos. 2003;25(6):643-9.

14. Hayrynen KL. The production of austempered ductile iron (ADI). Schaumburg: Modern Casting; 1995.

15. Kovacs BV. On the terminology and structure of ADI. AFS Transaction; 1994;94-93:417-20.

16. Hayrynen KL. ADI: another avenue for ductile iron foundries. Schaumburg: Modern Casting; 1995. p. 35-7.

17. Kovacs BV. Austempered ductile iron: fact and function. Modern Casting; 1990;80(3):38-41.

18. ASTM: American Society for Testing and Materials. ASTM A 897M-90: Standards specific for austempered ductile iron casting [Metric] 1. West Conshohocken: ASTM; 1997.

19. Wang B, Barber GC, Qiu F, Zou Q, Yang H. A review: phase transformation and wear mechanisms of single-step and dual-step austempered ductile irons. J Mater Res Technol. 2020;9(1):105469. http://dx.doi.org/10.1016/j.jmrt.2019.10.074.

20. Wang B, He M, Barber GC, Schall JD, Tao C, Sun X. Rolling contact fatigue resistance of austempered ductile iron processed at various austempering holding times. Wear. 2018;398-399:41-6.

21. Sellamuthu P, Samuel D, Dinakaran D, Premkumar V, Li Z, Seetharaman S. Austempered Ductile Iron (ADI): influence of austempering temperature on microstructure, mechanical and wear properties and energy consumption. Metals. 2018;8(1):53.

22. ABNT: Associação Brasileira De Normas Técnicas. NBR NM 187-1: Materiais metálicos - dureza Brinell. Parte 1: medição da dureza Brinell. Rio de Janeiro: ABNT.

23. Du Y, Gao X, Wang X, Wang X, Ge Y, Jiang B. Tribological behavior of austempered ductile iron (ADI) obtained at different austempering temperatures. Wear. 2020;203396:203396.

24. Campos-Cambranis RE, Narváez Hernández L, CisnerosGuerrero MM, Pérez-López MJ. Effect of initial microstructure on the activation energy of second stage during austempering of ductile iron. Scr Mater. 1998;368(8):1281-7. 